\title{
Teaching and Learning Chemistry: Contributions of Immersion Projects in Teaching to Teachers Training
}

\author{
Maria Luiza Silva Tupy Botelho \\ Ph.D. student in the Graduate Program in Education \\ Faculty of Education \\ Federal University of Minas Gerais, Brazil \\ Ana Luiza de Quadros \\ Ph.D. in Education, Associate Professor \\ Department of Chemistry \\ Institute of Exact Sciences, and of the Graduate Program in Education \\ Faculty of Education \\ Federal University of Minas Gerais, Brazil
}

\begin{abstract}
Training educators to teach Chemistry so to produce learning has been a challenge in teacher training courses. This study was developed aimed at analyzing the contributions of immersion projects in teaching to the understanding of teaching and learning process and the role of both teachers and students in the classroom dynamics. A questionnaire and a focus group were used for data production. Through content analysis, we noticed that teachers in training seem to understand the important discussions in the educational field, with promising chances of getting hold of them as teaching practices when they take on teaching.
\end{abstract}

Keywords: Teacher Training, Immersion Projects in Teaching, Chemistry Teaching.

\section{Introduction}

Teacher training at the undergraduate level is a recurring theme at the international sphere (Paredes, 2012). Orientations in the National Curriculum Guidelines for the Training of Teachers of Brazilian Basic Education (Brazil, 2002), despite omitting the actual working conditions in the school and the social and professional meaning of teaching, brought with it the need for changes in the format of licentiate degree courses and teacher training in general. Among these changes is the increased course hours of specific disciplines in the area of education, both in the curriculum component of teaching practice as in the curricular trainee ships (Maldaner, 2006).

However, the actions that seem to have most impacted the courses in this last decade were the programs and projects of immersion in teaching. Generally speaking, these projects were created to encourage the teaching career, favor processes of training and construction of the future educators' professional identity, insert the licentiate degree students in the Basic Education environment throughout the academic course, and to increase the bond between teacher training institutions and public institutions of Basic Education.

Our study was aimed at analyzing the conceptions of teachers in training participating in projects of immersion in teaching on the processes of teaching and learning, both regarding the role of teachers and students as the teaching methodologies, in addition to other concepts linked to teaching. Therefore, participants from two classes of the Institutional Program for Teaching Initiation (PIBID), in the Chemistry subproject, were investigated.

The PIBID was implemented in Brazil in November 2007 aimed at providing students of teacher training courses in public Higher Education Institutions with teaching initiation. The PIBID project of the Higher Education Institution where this research was developed started its activities in partnership with Basic Education institutions in 2009 and continues to do so up to date.

\section{Science Teachers Training: some considerations}

It seems to be a consensus that a school is a privileged place for the realization of changes aimed at the quality of the population education. As teachers are "key players" in the school dynamics, teacher training is a key element for the quality of teaching and, consequently, for learning to become a reality. Maldaner (2006) emphasizes teacher training as a "prerequisite" for improving the quality of education as a whole. 
In this sense, we searched in the literature for works involving teacher education at the undergraduate level and that dealt with immersion in teaching as a training process. In Brazil, PIBID, created in 2007, allowed numerous teacher training institutions to propose and develop projects for immersion in teaching.

From this, a significant number of studies began to be published, reporting diverse formative experiences. These studies dwell on the improvement of teaching for Basic Education students from the projects of teaching initiation (Silveira \& Schmidt, 2012; Santos, Silva \& Benaduce, 2013; Silva-Miguel et al., 2014; Silva, 2014; Paludo, 2014), the continuing education of Basic Education teachers involved in these projects (Afonso, Marques \& Marques, 2013; Nascimento Junior \& Gonçalves, 2013; Jardilino, 2014), or discussed such projects in the sphere of public policy (Garcia \& Higa, 2012). However, most studies (Corrêa \& Portella, 2013, Garcia, 2013; Lopes, 2014; Correia \& Manrique, 2012; Fetzner \& Souza, 2012; Schroeder \& Wendling, 2013; Cozza, 2013; Santos, 2013) deals with immersion in teaching as a tool that has brought broad contributions to teachers training at undergraduate level.

The studies cited in the previous paragraph are examples of the publication involving projects of immersion in teaching developed in teacher training institutions in Brazil. We chose to deal more specifically with those - both Brazilian as those found in the Education Resources Information Center (ERIC) - that are in line with the research we developed and report in this study.

Tan (2013) reflected on the emotions involved in the teaching and learning process. In this reflection, he does not consider emotions only as individual psychological constructs but extrapolates them to the individual's social context. According to the author, the study of emotions is of great importance for teachers training, and immersion projects in teaching are suitable spaces for future teachers to experience the teacher/student/knowledge relation as a relationship full of emotions.

Lehesvuori, Viiri and Rasku-Puttonen (2011) reported on the experience of Science teachers in training, participants in an immersion project in Finland, in which the communicative approach (Mortimer and Scott 2003) was attempted in classes developed by them. According to the authors, the future teachers became aware of the importance of inserting the student in the classroom discussions and made, throughout the project, attempts to use different discourses in the classroom. The authors declared the Finnish teachers in training reported a greater awareness of the teacher's role in educational dynamics and the challenge of trying to implement dialogic teaching.

Lobato and Quadros (2018) investigated how the discourse is constructed in classrooms of early-career teachers. As stated by the authors, the licentiate students investigated, when participating in the Motivational Practices Project, were able to experience other methodological possibilities for a Chemistry class. The authors emphasized that the licentiate degree students, besides reflecting on the teacher's role and on teaching and learning theories, sought to learn to teach, concretizing the connection between theoretical knowledge, school context, and teaching practice. This was reflected in the evolution of the two licentiate degree students investigated in the work of Lobato and Quadros (2018) regarding the use of discourse in the classroom, favoring a greater interaction between the subjects (teachers and students) and offering more opportunities for students to participate in classroom discussions. The importance of teaching initiation projects in teachers training is highlighted by the authors. According to them, these projects provide very significant formative experiences, while allowing the planning and follow-up of the classes developed by licentiate students, as well as the discussion and reflection of the initiatives taken by these future teachers.

Rodriguez et al. (2017) investigated the experiences of educators beginning in teaching and how these experiences could affect the practice of experienced teachers. For this, they investigated both beginner and experienced teachers from the province of León, Spain. According to them, novice teachers show a general sense of satisfaction with the period in which they started teaching but show that there are significant gaps in the initial teacher training that end up negatively influencing their professional development. These gaps eventually lead the inexperienced teacher to feel insecure and to manifest difficulties in dealing with organizational, social, material, and technological situations, especially outside the classroom, such as in attention to the students' parents. Rodriguez et al. (2017) summarize the research results stating that there is a gap between the training received and the practical needs identified by teachers. Siry and Martin (2014) report a work carried out with a group of licentiate students who participated in a project of teaching initiation in the United States. In the meetings held by the group - the teachers in training and the training teachers - the dialogue was used to awaken critical thinking and reflection on the actions taken by future teachers in the classroom. The authors report that, in these meetings, the group watched videos of classes developed at the school, discussing positive points and points that needed to be reassessed in the practice of these subjects. According to the authors, the future teachers were, in the course of the project, more open to the criticisms pointed out by the peers. Reflection on teacher action became more frequent in the discussions and the interest in teaching and research in the area of teaching surfaced. 
Tracz, Beare and Colleen (2018) conducted a longitudinal study concerning a partnership between the teacher training course and the Basic Education school, in a immersion project in teaching. Focal groups and interviews were used for this, with school teachers, teachers of the training course, and directors involved, in the first year of the project and seven years later. With this, they emphasized the change from the individual to the collective perspective, a more efficient emotional support, a more organized and intense curricular internship, as well as several other contributions.

In their paper, Murphy, Scantlebury and Milne (2015) report their experience in a teaching immersion project, anchored in Vygotsky's zone of proximal development (2009). The work involved in-training and in-service teachers and was intended to assist future educators in understanding the teaching and learning process and in building a work tool to help them organize school activities. According to the authors, this experience reduced the distance between theory and practice, developed reflective practice and pedagogical knowledge of the content.

Several contributions of immersion projects in teaching were highlighted in the literature. In addition to those already mentioned, there is a return to the "pleasure" of teaching and valuing the teaching career (Quadros Souza, 2014), the construction of new perspectives on the teaching profession and the explicit intention of $n$-training teachers to become actual teachers (Matos and Souza Carvalho, 2014), the overcoming of negative prejudices that subjects involved in the PIBID had in relation to the public schools of Basic Education (Tinti, 2012), in addition to other important perceptions that show the positive contribution of the projects of immersion in teaching.

Teixeira Junior (2014), evaluating the role of PIBID in teacher training, investigated 160 Chemistry teachers in training, PIBID grantees, from 21 subprojects in five different regions of Brazil. He declared these projects have enabled the learning about teaching and highlighted the possible positive impacts for the initial training of Chemistry teachers and for the Basic Education schools participating in the Program.

Pena (2016) investigated how in-training teachers used context-based didactic material to develop Chemistry classes in Basic Education. According to the author, the teaching material influenced the appropriation of some contemporary tendencies of teaching and learning or, at least, the reflection on these tendencies. She reiterates that only the use of an innovative material is not sufficient to provoke great changes in the performance of these teachers and that this use must be accompanied by deep reflections guided by theory, in courses of initial and/or continuing teacher training. Pena (2016) emphasizes the importance of initiation projects in teaching, by giving teachers in training the opportunity to practice "other ways" of developing classes.

Our research is in line with this search for new meanings that projects of immersion in teaching can offer to those participating. Our hypothesis is that experiencing these projects contributes to understanding of the teaching and learning process, especially the role of teachers and students in the classroom dynamics.

\section{Methodology}

This research was carried out using a qualitative methodological approach. For its accomplishment, a questionnaire was developed and employed and, from the data obtained, a focal group was organized. The data produced in both instruments were examined based on the Content Analysis methodology, proposed by Bardin (1977).

The questionnaire was produced by the researchers and consisted of three groups of questions. The first one was proposed to characterize the research participants. A second group sought to identify the reasons that led the teachers in training to choose a Chemistry teacher training course and their intention of acting in Basic Education after graduating. The third group was more specific, with questions involving the role of teachers and students in the classroom, and some situations with which other conceptions related to teaching and learning were sought. A search was conducted together with the coordinators of the PIBID groups mentioned above, to identify participating in-training teachers. The questionnaire was sent to 37 of them and 21 questionnaires were returned answered.

A survey of the data present in the questionnaires received was conducted and, from these data, the next phase was organized (focus group). It should be noted that the focus group was proposed aimed at reducing the degree of inference in the data analysis, as well as to aggregate information that would allow a better understanding of the participants' ideas.

For the focus group, some discussion blocks were organized. One should highlight in this study: the "participants' intent in working in Basic Education after graduation", to understand what led some teachers in training to change their idea regarding the professional activity in the area of education during the academic trajectory; "the students' lack of interest in Science classes," to reinforce the discussion about the factors responsible for the students' lack of interest in Science and the content, in the school environment, which had already appeared in the questionnaire; the "planning of classes," with the intention of comprehending the understanding of these subjects on the function of planning for the teaching work; from a fictitious classroom situation in which Science was questioned by a student, one sought to understand how teachers in training dealt with controversial situations, or their understanding of Science itself. 
The focus group meeting was recorded on video and the discussions were transcribed in full. Participants were identified by the initials TT (teacher in training) followed by a number (1 to 21) provided to each of them, so to protect anonymity.

\section{Results and Discussion}

Results were organized into five themes, using data from both the questionnaire and the focus group. Each of them will be discussed below.

\subsection{The choice of course and professional perspectives}

Participants were asked to justify the choice for the Chemistry teacher training course when they enrolled for the university and the professional perspective after experiencing the teaching in extracurricular internships and during the project of immersion in teaching. Table 1 summarizes the data of these two issues.

Table 1: Options related to the profession

\begin{tabular}{c|c|c}
\hline Professional intent & $\begin{array}{c}\text { When joining the } \\
\text { Course }\end{array}$ & $\begin{array}{c}\text { After immersion in } \\
\text { teaching }\end{array}$ \\
\hline Working in Basic Education & 14 & 14 \\
\hline Working in Higher Education & 0 & 04 \\
\hline Working as a Chemist & 7 & 01 \\
\hline Undecided & 0 & 02 \\
\hline
\end{tabular}

Source: Research data

The Chemistry teachers training course happens in the night period, different from the course of Chemistry, which happens in the daytime. When making the course option, seven of them affirmed a preference for Chemistry but enrolled in the teacher training course because it was the only one in the night shift, which would allow them to work in the daytime and study at night. However, after participating in the project of immersion in teaching, four of them seem to have changed their option and two others are undecided about the future profession.

It is worth mentioning that the evasion of Chemistry teachers training courses is greater than in chemistry courses. This is due in part to the fact these students get to know better the work conditions in Brazilian schools (low salary, poor physical structure of schools, among other problems). However, with this group of teachers in training the result is different. We have found, therefore, data similar to those found by Garcia (2013), Fetzner and Souza (2012), and Schroeder and Wendling (2013), who highlighted in their works the rich learning space that teaching immersion projects provide for future educators.

It was noted that four professors in training stated their intention to act as teachers in Higher Education. They emphasized in the responses to the questionnaire and in the focus group discussions that the precariousness of the Brazilian Basic Education system and the devaluation of teachers working in this segment led them to seek another possibility to act as teachers.

\subsection{Teaching and Learning: the role of teachers and students}

Participants were asked in the questionnaire about the role of teachers and students in the teaching and learning process. Based on the socio-historical theory and the importance of mediation in the classroom, we established, for the teacher's role, the categories of "responsible for facilitating learning" and "transmitter" of information. And for the role of the student in the classroom dynamics, we organized the answers in the categories "active" and "passive".

In Table 2, we associate the answers regarding the role of the two actors in the classroom, as follows:

Table 2: The actors in the classroom

\begin{tabular}{l|c|c}
\hline \multicolumn{1}{c|}{ Teacher } & Student & Number of associations \\
\hline Responsible for facilitating & Active & 17 \\
\cline { 2 - 3 } learning (18) & Passive & 01 \\
\hline $\begin{array}{l}\text { Responsible for transmitting } \\
\text { information (03) }\end{array}$ & Active & 01 \\
\cline { 2 - 3 } & Passive & 02 \\
\hline
\end{tabular}

Source: Research data 
The category "responsible for facilitating learning" includes the answers that showed a broad view of the teacher's role in the classroom, highlighting one of them, which may be representative of the others.

The teacher must be much more than a transmitter. In the classroom, they should instigate students, create an environment conducive to learning, and conduct discussions and situations that contribute to the formation of critical thinking and scientific reasoning. (T.T. 12)

One can see that, by placing the teacher as responsible for facilitating learning, the student has also been placed in an active posture, that is, as someone who participates and becomes involved with the class activities. Only one teacher in this group seems to be unclear about the role of these actors, placing the student as passive in the classroom dynamics.

Three other participants placed the teacher as transmitter of information and, of these, two consider that the student should have a more passive role in the classroom. These are teachers in training who participated in the immersion project in teaching for a maximum period of six months. It seems that conceptions about the role of students and teachers were not sufficiently discussed for these subjects.

We have considered that learning is related to the involvement of the learning subjects in activities and discussions, mediated by both language and mediating objects. Learning takes place at the social level, through the discussion of different ideas, and at the individual level, when the apprentice grasps a new idea (Vigotski, 2009) because it seems more coherent to them (Driver et al., 1994). Seventeen participants have demonstrated they have seized the perspective of making the classroom a space for the discussion of ideas (social plan), making the student a protagonist and thus favoring him/her to get hold of new ideas (individual plan).

Thus, one can consider that seventeen licentiate degree students showed signs of having constructed a more elaborate view of the teaching and learning process. Possibly, for these licentiate students, the model of transmitting and receiving information, without being signified, has no space in the classroom.

\subsection{Explaining students' "disinterest" in classes}

In the questionnaire, comments on the students' lack of interest in the classes in general, and mainly in Science classes, were recurrent, as was the affirmation that this discourse is present among in-service teachers, graduate teachers, school boards and, in short, a large part of the people involved in the teaching and learning process. During the focus group, we asked the participants to discuss this disinterest. In constructing arguments, we have identified those "responsible" for this supposed lack of interest. Table 03 shows the main "responsible" for the students' possible disinterest in the classes and the number of answers that were classified in each one.

Table 03: Reason for the students' lack of interest in classes

\begin{tabular}{c|c}
\hline Category & Total number of citations for the category \\
\hline Teacher & 16 \\
\hline System & 03 \\
\hline Student & 03 \\
\hline
\end{tabular}

Source: Research data

We selected an excerpt of the speech from each of the above categories, representative of the statements that "blame" actors for the students' lack of interest in Science/Chemistry classes.

For me, the main cause that leads to disinterest is the disconnection between the Science content in the classroom and the students' daily life. Scientific concepts are studied or memorized only for the test, without any understanding. This lack of relationship between content and context leads to disinterest. What is that for, then? (T.T. 19 - blaming the teacher)

There are several reasons. One of them is to regard everything as a 'joke'. Today's students do not know how important it is to have information and knowledge to become more cultured people. The teacher often makes a huge effort and the student does not value it. (T.T. 5- blaming the student)

The students' lack of interest is due to several factors and I emphasize the fact that professional success is not tied to learning and scientific training, and the student realizes this, and, also, the fact that teaching and the teaching profession are not valued. (T.T. 16 - blaming the "system")

We know that developing classes focused on the transmission of information, overuse of classifications, and with little relationship between content and context are some of the factors that reinforce the idea that Science is not part of citizens' lives and discourages students to learn Science (Driver et al., 1994; Lehesvuori, Viiri \& Rasku-Puttonen, 2011; Lobato and Quadros, 2018) and this seems to be evidenced in the speech of T.T. 19. And T.T. 5, in turn, highlighted the students' lack of maturity. 
In the category "system" are organized the answers that affirmed that this problem has a broader origin. In the case of T.T. 16, the commentary involves both the students' perception about our society and the low value of education in Brazil.

In dealing with students' lack of interest in Science classes, 16 participants (out of 21) stated that the responsibility for such disinterest lies in the teacher's performance. According to this information, the licentiate students regard the way the teacher deals with the content and the little interaction they promote in the classes as responsible for this disinterest.

\subsection{The planning of classes}

We created a hypothetical situation to investigate how the teachers in formation would do the planning of a lesson. In this situation, they would be the regent teacher in a public school and should develop a class or a set of classes to work knowledge concerning chemical equilibrium. The intention was to see if, in this planning, the class would have a more innovative design (not focused on the simple transmission of information).

Of the 21 participants, five of them described a class that we could classify as traditional, that is, centered on the transmission of information. In two cases, the teachers in training described the use of experiments, but these had the function of exemplifying a knowledge already worked in class. In this group, there are the three teachers in training who have up to six months of experience in the project (already highlighted in item 4.2). For the other two, we can see that there is an innovative discourse but the teaching practice tends to be traditional.

The other 16 participants referred to the use of experiments, investigative activities, thematic activities, reading texts, modeling, among other tendencies. Of these, three did a more detailed planning that allowed us to understand how this lesson would be developed. These three teachers in training organized the planning around a theme and highlighted didactic strategies that would be used to construct the scientific concepts needed to understand the chemical equilibrium, such as the questions they would ask the students, the experiment to be used, and the activities that would make the students protagonists. We have no doubt they grasped the discourse that circulates within the projects of immersion in teaching. The others were more generalist and we believe the fact that planning requires considerable time may have contributed to their less detailed description of the lesson they would teach to work on the chemical equilibrium content.

In the focus group, we resorted to the role of planning in the organization of classes, seeking to understand possible contributions of immersion projects in teaching to the understanding of planning and its importance. The participants were unanimous in defending the importance of well-designed planning with well-defined objectives. According to them, the first contact they had with this activity was in the Projects of Immersion in Teaching and, later, in the curricular internships. Planning is considered by them as an important stage of the teaching practice. However, they believe that, with working time and experience, planning becomes a daily and mental activity as they seize some contemporary trends in teaching and learning, making the classroom an environment conducive to learning.

\subsection{A controversial case in Chemistry classes}

Another hypothetical classroom situation was addressed in the questionnaire. In it, a student brings to discussion a controversial case, related to the causes of the greenhouse effect and global warming. In this hypothetical situation, a student mentions a reporting that puts global warming as a natural phenomenon, without the influence of human interference. We asked the teachers in training to imagine themselves experiencing this situation in the classroom and tell us what their posture would be if it happened in one of their classes.

This question, in our understanding, is directly related to the production of knowledge and the provisionality that certain knowledge can assume. We aimed at understanding how the teachers in formation would deal with the fact, especially the vision of Science, that is, whether it would be considered as an explanation or as an unquestionable truth. Of the 21 participants, eleven affirmed that they would give a voice to the students or propose a debate to discuss the theme in question, or that they would allow the students to discuss with each other to reach a consensus on the topic addressed. By signaling to giving students a voice and considering the questions/explanations they bring to the classroom, these teachers are making them protagonists in the classroom and possibly promoting discursive interactions conducive to the appropriation of knowledge. We highlight a response (T.T.14) provided in the questionnaire, which is representative of this group.

I believe I would ask the student to provide more details about the reporting. I would ask if the other students have ever seen any reporting or information similar to that. Then I would ask whether they agreed with this reporting and to justify it with evidence. As I have also heard about this point of view, in the end I would agree that this is also a point of view of some scientists and that this is a common feature that refers to the Nature of Science, that there is almost never a single point of view on some controversial subject. 
Perhaps I would ask for more detailed research, debate on the subject, and emphasize the importance of positioning face these controversial issues. In fact, these controversial subjects are very good for problematizing and enabling the discussion of scientific contexts in the classroom. (T.T. 14)

T.T. 14 makes clear the understanding of Science as a way of explaining contextual phenomena and that, even within this Science, the explanations can be different and even controversial. According to him, exploring these controversial situations may be conducive to the understanding of Science itself. As already mentioned, eleven participants assumed the same posture as T.T. 14.

Other than this group, the ten other trainees hinted that they would explain to the student about the situation he brought to the classroom, as if Science had the "answer" to the problem. Lederman (1992), in a literature review, found that the different professors investigated in the analyzed works presented inadequate conceptions about the Nature of Science. In a more recent study, Quadros and Mortimer (2018) reaffirm that an expressive number of teachers considers scientific knowledge to be "proven" through sophisticated experiments. And it is common that, in communicating this Science to students, they do not treat it as a plausible explanation and therefore subject to revisions.

In order to better understand this conception, we return to the discussion on the subject in the focus group. We then presented two answers that had been provided in the questionnaire, omitting, at that moment, the authorship of both: one that, in our view, considers the Nature of Science and another that does not consider it, as a way of resuming the subject.

At that moment, it seemed almost consensual the importance of discussing, in the school environment, that Science is a historical, social, and cultural construction. However, it was at the moment when the participants were asked for a justification for the different posture perceived in the questionnaire, that the difficulties arose. They cited the time needed to hold discussions that could help students understand how Science is constructed and stated that, in the Chemistry teachers training course in which they participate, they are not prepared for it.

Although we notice an understanding about Science, we realize that there are still conceptions that need to be improved because the difficulty of knowing how to deal with this in Basic Education classes remains. In the literature, there are countless studies (e.g., Praia et al., 2007; Brito, Souza \& Freitas, 2008; Chinelliet al., 2010) reporting the difficulty faced by teachers (in training and in exercise) in inserting the Nature of Science in their classes. The subjects investigated in this study presented adequate conceptions about the Nature of Science, resulting from the involvement with projects of immersion in teaching. This data is an important indication of the importance these projects have to teacher education in Brazil.

\section{Final Considerations}

Our intention in carrying out this work was to investigate the contribution of immersion projects in teaching for teachers education, to provide a more solid training and in line with the specialized debate in the field of Science Education. To this end, were analyzed mainly the discourse of the teachers in formation who are participants in these projects.

We observed that a significant number of these teachers in formation presented a discourse that is in line with what has been discussed in the area of Science Teaching and which has been dealt with in the specialized literature. We can affirm that the experiences lived in the Projects of Immersion in Teaching were favorable to the formation of these future teachers because we believe that, for these subjects, the instruction based on the mere transmission of information no longer has place in the classroom.

Our attention was drawn to the fact that some of them, at the time the data were collected, were already included in the field of work, reporting limitations or potentialities in dealing with some contemporary tendencies of teaching and learning addressed in the research. It is no longer an indication but a practice organized from the experiences lived in these projects. As Zanon (2003) argued, the in-training teachers involved in this work also consider teaching as a complex activity, for which it is not enough to know the specific content, although this knowledge is a prerequisite for teaching.

We have no doubt about the importance of teachers in training having contact with the field from the beginning of the training course. And, above all, the fact that they can enter into a "way" of teaching different from the one in which they were formed. It is in this insertion that the teaching practice can be reflected, and this reflection be anchored in the teaching and learning theories. As emphasized by Teixeira Junior (2014) and Zanon (2003), theoretical knowledge is inseparable from teaching practice. Like them, we emphasize the relevance of new research involving projects of immersion in teaching, which seek new meanings for teaching training and also for the performance of future Chemistry teachers. We have no doubt about the contribution of immersion projects in teaching to teacher training. 
However, learning must go beyond this perception: what are the teacher education courses in Brazil learning from these projects? What is being seized by these courses? It is extremely important that - in the face of so many contributions this appropriation takes place, so that teacher training does not become dependent on extracurricular projects.

\section{References}

Afonso, A. F.; Marques, R. N. \& Marques, C. M. P. (2013). O papel do professor da escola de educação básica que recebe os bolsistas de iniciação à docência de Química. Enseñanza de las ciencias, 31(Núm. Extra), 13581362.

Bardin, L. (1977). Análise de Conteúdo. Lisboa: Edições 70.

Brasil (2002). Conselho Nacional de Educação. Diretrizes Curriculares Nacionais para a Formação de Professores da Educação Básica. Resolução CNE/CP, n. 1.

Brito, L.; Souza, M. \& Freitas, D. (2008). Formação inicial de professores de ciências e biologia: a visão da natureza do conhecimento científico e relação CTSA. Revista Interacções, 4(9), 129-148.

Chinelli, M. V.; Ferreira, M. V. S. \& Aguiar, L. E. V. (2010). Epistemologia em sala de aula: a natureza da ciência e da atividade científica na prática profissional de professores de ciências. Ciência \& Educação, 16(1), 17-35.

Corrêa, P. M. \& Portella, V. C. M. (2013). As pesquisas sobre professores iniciantes no Brasil: uma revisão. Olhar de Professor, v. 15, n. 2, p. 223-236, 2013.

Correia, G. S.; Manrique, A. L. (2012). A Contribuição do projeto PIBID-PUC/SP na formação inicial dos licenciandos de Matemática e física. In: C. A. B. Santos; N. S. G. Allevato; L. H. Amaral, \& E. Curi (eds.). Ensino de ciências e matemática: a produção discente na Pós-graduação (pp. 161-169). São Paulo: TERRACOTA.

Cozza, F. E. (2013). Modelagem Matemática: Percepção e Concepção de Licenciandos e Professores. Dissertação (Mestrado em Educação) - Programa de Pós-Graduação em Educação em Ciências e Matemática. Pontifícia Universidade Católica do Rio Grande do Sul. Rio Grande do Sul/Brasil.

Driver, R.; Asoko, H.; Leach, J.; Mortimer, E. F. \& Scott, P. (1994). Constructing scientific knowledge in the classroom. Educational researcher, 23(7), 5-12.

Fetzner, A. R. \& Souza, M. E. V. (2012). Concepções de conhecimento escolar: potencialidades do PIBID. Educação e Pesquisa, 38(3), 683-694.

Garcia, L. V. (2013). A formação docente nos subprojetos Química do Programa Institucional de Bolsa de Iniciação à Docência. Dissertação (Mestrado em Educação em Química) - Programa de Pós-Graduação em Química. Universidade Federal de Uberlândia. Minas Gerais/Brasil.

Garcia, N. M. D. \& Higa, I. (2012). Formação de professores de Física: problematizando ações governamentais. Educação: Teoria e Prática, 22(40), 166-183.

Jardilino, J. R. L. (2014). Políticas de Formação de Professores em conflito com o currículo: Estágio Supervisionado e PIBID. Educação (UFSM), 39(2), 353-366.

Lederman, N. G. (1992). Student's and teacher's conceptions of the nature of Science: A review of the research. Journal of Research in Science Teaching, 29(4), 331-359.

Lehesvuori, S.; Viiri, J. \& Rasku-Puttonen, H.(2011). Introducing dialogic teaching to science student teachers. Journal of Science Teacher Education, 22(8), 705-727.

Lobato, A. C. \& Quadros, A. L. (2018). How the discourse of new professors is made up in the classroom. Revista Educação e Pesquisa, 44(1), 1-20.

Lopes, M. F. (2014). As dores e amores de tornar-se professora: minhas memórias de professora iniciante. Dissertação (Mestrado em Educação: Arte, Linguagem, Tecnologia) - Programa de Pós-Graduação da Faculdade de Educação. Universidade Federal do Rio Grande do Sul. Rio Grande do Sul/Brasil.

Maldaner, O. A. (2014). A formação inicial e continuada de professores de Química. 3. ed. rev. Ijuí: Ed. Unijuí.

Matos, C. C. \& Souza Carvalho, J. V. (2014). Vivências formativas no curso de licenciatura em Química: construindo novos olhares sobre a docência. Cadernos de Educação, Tecnologia e Sociedade, 5, 213-220.

Mortimer, E. F. \& Scott, P. (2003). Meaning Making In Secondary Science Classrooms. McGraw-Hill Education (UK).

Murphy, C.; Scantlebury, K. \& Milne, C. (2015). Using Vygotsky's zone of proximal development to propose and test an explanatory model for conceptualising coteaching in pre-service science teacher education. Asia-Pacific Journal of Teacher Education, 43(4), 281-295.

Nascimento Junior, A. F. N. \& Gonçalves, L. V. (2013). Oficina de jogos pedagógicos de ensino de ecologia e educação ambiental como estratégia de ensino na formação de professores. Revista Práxis, 5(9), 71-76.

Paludo, L. (2014). Uma proposta para a introdução ao uso de tecnologias no ensino de física experimental dirigida a licenciandos de física. Dissertação (Mestrado Profissional) - Programa de Pós-Graduação em Ensino de Física. Universidade Federal do Rio Grande do Sul. Rio Grande do Sul/Brasil. 
Paredes, G. O. (2012). Um estudo sobre o PIBID: saberes em construção na formação de professores de Ciências. Dissertação (Mestrado em Educação) - Programa de Pós-Graduação em Educação em Ciências e Matemática. Universidade Federal do Paraná. Paraná, Brasil.

Pena, D. M. B. (2016). Do planejamento à prática: a influência de um material didático na prática de um grupo de professores em formação em Química. Dissertação (Mestrado Educação e Ciências). Programa de PósGraduação da Faculdade de Educação da Universidade Federal de Minas Gerais, Brasil.

Praia, J.; Gil-Pérez, D. \& Vilches, A. (2007). O papel da natureza da ciência na educação para a cidadania. Ciência \& Educação, 13(2), 141-156.

Quadros Souza, R. M. (2014). O Programa institucional de bolsas de iniciação à docência numa universidade da grande São Paulo: depoimentos, contradições e reflexões preliminares. Acta ScientiarumEducation, 36(2), 309-316.

Quadros, A. L. \& Mortimer, E. F. (2018). Aulas no Ensino Superior: estratégias que envolvem os estudantes. 1. ed. Curitiba: Appris.

Rodriguez, R. C.; Mmayo, I. C.; Gago, A. R. A. \& Álvarez, R. B. (2017). Initiation into Teaching from the Perspective of Primary School Teachers: Differences Between Newly Qualifed and Experienced Teachers. Journal of new Approaches in Educacional Research, 6(2), 103-111.

Santos, L. P.; Silva, F. \& Benaduce, G. M. C. (2013). Aromas e sabores: uma abordagem geográfica na educação ambiental. Revista Eletrônica do Curso de Direito da UFSM, 8, 559-571.

Santos, S. (2013). Formação Inicial e Prática Docente: Percepções de Futuras Professoras. Olhar de Professor, 15(2), 355-369.

Schroder, T. M. R. \& Wendling, C. M. (2013). Contribuições do PIBID para a formação do pedagogo. Contribuciones a las Ciencias Sociales, 9, 1-13.

Silva, D. F. (2014). Processo de Iniciação à Docência de Professores de Matemática: olhares de egressos do PIBID/UFSCar. Dissertação (Mestrado em Educação) - Programa de Pós-Graduação em Educação. Universidade Federal de São Carlos. São Paulo, Brasil.

Silva-Miguel, K.;Campos, I. A. O. B.; Knechtel, C. M.; Ferraz, C. M. \& Justina, L. A. D. (2014). Investigative courseware approach in high school: a study about DNA. ETD: Educação Temática Digital, 16(2), 119-134.

Silveira, C. M. \& Schmidt, L. L. (2012). A percepção de uma adolescente multirrepetente sobre sua trajetória escolar. Poiésis-Revista do Programa de Pós-Graduação em Educação, 5( 9), 300-317.

Siry, C. \& Martin, S. N. (2014). Facilitating reflexivity in preservice science teacher education using video analysis and cogenerative dialogue in field-based methods courses. Eurasia Journal of Mathematics, Science \& Technology Education, 10(5), 481-508.

Tan, S. C. (2013). Social cultural and situative perspective of studying emotions in teaching and learning: characteristics, challenges and opportunities. Cultural Studies of Science Education, 8(3), 553-560.

Teixeira Junior, J. G. (2014). Contribuições do PIBID para Formação de Professores de Química. Tese (Doutorado em Química) - Programa de Pós-Graduação em Química. Universidade Federal de Uberlândia. Minas Gerais, Brasil.

Tinti, D. S. (2012). PIBID: um estudo sobre suas contribuições para o processo formativo de alunos de Licenciatura em Matemática da PUC/SP. Dissertação (Mestrado em Educação Matemática) - Programa de Estudos PósGraduados em Educação Matemática. Pontifícia Universidade Católica de São Paulo. São Paulo, Brasil.

Tracz, S. M.; Beare, P. \& Torgerson, C. A. (2018). Longitudinal Case Study of a University Partnership for TrainingTeachers. Journal of School Administration Research and Development, 3(1), 42-56.

Vigotski, L. S. (2009). A construção do pensamento e da linguagem. $2^{\mathrm{a}}$ ed.(trad. Paulo Bezerra). São Paulo: WMF Martins Fontes.

Zanon, L. B. (2003). Interações de licenciandos, formadores e professores na elaboração conceitual de prática docente: módulos triádicos na licenciatura de Química. Tese (Doutorado em Educação) - Programa de Pós-Graduação em Educação. Universidade Metodista de Piracicaba, São Paulo, Brasil. 